\title{
Analysis of The Cycling Trend During the Pandemic of COVID 19 Towards Small and Medium Enterprises (UMKM) Income
}

\author{
Irham Ramdani ${ }^{*}$ \\ ${ }^{1}$ Universitas Indraprasta PGRI, Jagakarsa, Indonesia
}

\section{A R T I C L E I N F O}

Article history:

Received 18 August 2020

Received in revised form

5 September 2020

Accepted 18 October 2020

Available online 01

November 2020

Keywords:

Pandemic, Bicycle, Small-

Medium Enterprises

(UMKM) voice showing the increase of small and medium bicycle enterprises's income, so we can conclude that there is an impact of the cycling trend during the pandemic of COVID 19 towards the increase of the small medium bicycle enterprise, whether it is online, offline, the selling of bicycle, the spare parts, or the accessories.

Copyright () Universitas Pendidikan Ganesha. All rights reserved.

\section{Introduction}

In the early 2020, the world was shocked with the Corona Virus Disease pandemic (COVID-19) who managed to infect most of people all around the globe (Al-Balas et al., 2020; Nasution et al., 2020). Since January 2020, WHO has announce a global crisis amid the virus attack, this is a terrible phenomenon throughout the $21^{\text {st }}$ century, on the same scale of World War II, because the majority of world biggest events (such as sports events) has been postponed or even worse canceled, The similar condition as we are having now were only happened once, it is when the Word War occurred, there are no other circumstances that can canceled those events before . Starting from March, 19th 2020, there are 214.894 confirmed case of infection, 8.732 are pronounced dead, 83.313 are fully recovered from this disease. (AlBalas et al., 2020; He et al., 2020).

In Indonesia, the government has pronounced the state of a disaster emergency, starting from February $28^{\text {th }} 2020$ to May 29th 2020 amid the pandemic for 91 days straight. The mitigation step has been taken by the government to overcome this extraordinary case. One of the step is socializing the social distancing act (Hadiwardoyo, 2020; Handayanto \& Herlawati, 2020). This concept explain that one should maintain their safe distance minimum 2 meters away from another to cut the spread of COVID-19 virus. Besides, one must avoid direct contact with another, and also avoid a mass crowd. But there are people who does not obliged to this rules, Even though the government has already closed the school and university from the academic purposes and give the Work From Home policy for the employees, the people missed used it and went on vacation (Yamali \& Putri, 2020). Besides, despite the state of emergency the mass religious meeting was still held in several location, in contrary if the social distancing rules, in this kind of event, surely a mass group of people gathered in one place could be a perfect way to be infected, because the merrier the bigger the chance to get exposed by the COVID 19.

The COVID 19 pandemic not only affect health sector, but also give a positive effect on Indonesia's economic sector. It is the opening of new and bigger export market other than China. Besides, the domestic economy sector will also increase because the government will enhance the domestic 
production and take the bigger advantage from the foreign party. The COVID 19 pandemic can also be used as the correction so that despite the pandemic, the investment will always be in stable condition (Nasution et al., 2020).

In this pandemic situation, people share their common fear of getting infected by the incurable COVID 19. This forced the people to lock themselves in their house hoping that they are saved and protected from the virus infection. Though that staying at home make them feel save from getting infected but this does not mean that they are fine to lock themselves at home. In fact, they feel bored by the restriction of going anywhere, plus this condition been going on for too long. So, the people started to make various of trends during this time, that is why the treed of cycling has increased significantly.

The cycling trend has been spread throughout many circles in the society in the cities of Indonesia. This trend has attack various range of ages, from kids to elders. They love this cycling trend because they think that cycling can took away the bored yet they can always maintain the distance among others. This is why they choose to went cycling.

The establishment of cycling culture were affected by policies that support the riders, the policies that we spoke about is the local and national policies. Because, however the national rules could affect the local government to make a similar decisions and policies. Although there are some obstacles regarding the interest of the local officials, these policies include the establishment of a proper infrastructure and facilities, traffic arrangements, utilization of the cycling areas, and the safety of the riders. These policies will encourage people to use bicycle in their activities, because it has been arranged and protected by the law (Adityo, 2017)..

Bicycle is not only used for exercise but also used for hobbies while spending time at home. Building a bicycle from scratch to become a magnificent yet expensive piece. This is the reason why the demands of bicycle's spare parts are increasing and also leads to a wide-open selling opportunity for the Medium Small Enterprise in the pandemic era.

Indonesia is one of the affected country (of the pandemic) in the economic sector (Pakpahan, 2020), COVID 19 pandemic has brought many effect on the economics, such as the lack of working opportunity, the difficulty to complete daily needs, the lack of income, and any other economics difficulty amid the pandemic of COVID 19 (Hanoatubun, 2020).

The small and medium enterprise is the leading sector in this economic shock amid the COVID 19 pandemic, the lockdown state has suddenly stopped the economic activity which leads to the decreasing of demand and interfere the global supply chain (Handayanto \& Herlawati, 2020). In this pandemic affect the income of small medium enterprise.

Table 1. Impact of COVID-19 on UMKM

\begin{tabular}{ll}
\hline Impact & Percentage (\%) \\
\hline Decrease in Sales & 56,0 \\
Capital difficulties & 22,0 \\
Product distribution barriers & 15,0 \\
Raw material difficulty & 4,0 \\
\hline
\end{tabular}

Source : (Nasution et al., 2020)

From the table above, we can see that their similar case of reduction and other obstacles. The economic effect amid the pandemic was also felt by the small medium enterprises, because the small medium enterprises has been plotted in strategic position in the general economics. In ASEAN, small medium enterprises make nearly $50 \%$ to $95 \%$ working field and contributes between $35 \%$ to $50 \%$ of the GDP (Islam, 2020). In Indonesia, small medium enterprises are one of the strategic sectors of the national economic. It can be seen from the absorption of the manpower (Abidin, 2015). The small medium enterprises have been hit hard by the COVID 19 crisis, many of them were closed, collapsed, event further facing the cash flow difficulties (Baker \& Judge, 2020).

Despite COVID 19 pandemic brings up several problems for the small medium enterprise and cooperative practitioner, on the other hand it also brings some new opportunities. Our small medium enterprise and cooperative practitioner can use the information technology and communication considering the electronic commerce in 2020 hit US \$ 130 billion. The trading transaction for several products are increasing drastically during the COVID 19 pandemic, such as health products $90 \%$, hobbies supporting products $70 \%$, food products $350 \%$, and herbal food products $200 \%$. (Amri, 2020)

The impact of COVID 19 pandemic can be seen from the side of offer and the side of demand (Pakpahan, 2020; Yamali \& Putri, 2020). From the side of offer, there are many of the small and medium enterprise lacking the man power, this happen because of the health and social distancing reasons, many 
of the workers does not want to go to work as long as the COVID 19 is still exist. There comes two sides as the effect of the market competition, the succeed side because the condition forced the enterprises to be innovative in creating products and giving the best service for the market, so they consider this as a motivation, the other side is the failure side, because the condition has weakened the static enterprises who are afraid of the competition and incapable of creating best quality product, so they consider this condition as a thread for their enterprises (Sudaryana et al., 2020). On the side of the offer, the decreasing of the demands of goods and services makes the small medium enterprise cannot function optimally that leads into the decreasing of enterprise's liquidity. This condition, forced the people to lose their income because the small medium enterprise cannot afford to pay their wage. In worse case, the enterprise can do an unfair dismissal to their employees. An insufficient amount of capital from the operational production of the small medium enterprise is the main problem causing the growth problem of the enterprise, although on the other hand the banks says the contrary (Ardiansyah, 2019).

They are lot of business opportunity in the middle of the present grave economics condition, whether it is in a small scale or large scale. Business in the domain of health and environment cleanliness has a promising chance (Rohmah \& Syari, 2020). There are many of the government policies are create to save the small medium enterprises from falling, but there are also several domains on the small medium enterprises area that are well grown in this pandemic situation such as the masks, health utilities, plants, vitamins, bicycle, and many others. Various policies have been made by the Indonesian government to deal with COVID 19 pandemic, some of them bring out the positive effects, some of them are not because it is triggering the falling of the economics growth in Indonesia. The impact of this pandemic on the economics sector is the layoff of the employees, PMI Manufacturing Indonesia, the decreasing of the export, the inflation, and a big loss in the domain of tourism that cause the decreasing number of employment (Yamali \& Putri, 2020)

The short term policies that applied are monetary aid in the form of soft loan or aid in cash transfers involving a direct participation of the private sector. Meanwhile the long term strategies is to induct and utilize the digital technologies as the preparation to enter the industrial revolution 4.0 (Pakpahan, 2020). This encourage the small medium enterprise to get familiar with the emerging technologies so that they can survive the pandemic. They have to look for any possible strategies and make maximum profit out of it. This research is aim to analyze the impact of the cycling trend during the pandemic towards the income of small medium enterprise, especially who are in the bicycle domain.

\section{Methods}

This research uses the approach of qualitative descriptive, using the secondary data comes from various source such as books, articles, and homepage to access the latest data and information regarding the cycling trend during the COVID 19 pandemic.

The utilization of descriptive qualitative method was meant to give the specific description and visualization to answer the research question about how is the increase of small medium enterprise income as an impact of the COVID 19 pandemic. According to Sugiono (2007) the procedure of a research is divided to three main steps, the first one is the description or the orientation step, reduction step, selection step, then proceed to problem identification, setting the problem barrier and context, setting the research focus, data collecting, data processing, and data analyzing, theoretical writing, and result reporting.

The form of this research is analytical description, it is giving an education and an understanding to the readers, the data used in this research are the secondary data, the analytical of the data involved an interview, arranging the data into various kinds of different forms depends on the information source, then the data is served in a description manner in form of narrative text. 


\section{Results and Discussions}

\section{Research result}

The beginning of cycling trend is approximately on March 2020, It can be seen from the increase of the demands of bicycle in online application (Krisdamarjati, 2020). It was no surprise that there are a lot of the people are riding the bicycle in their daily activity after that. This trend gives the bicycle manufacturer an advantage. If normally they could only sell two units per month, ever since the trends they experience the increase of unit selling, they could reach four selling in a month (Jannah, 2020).

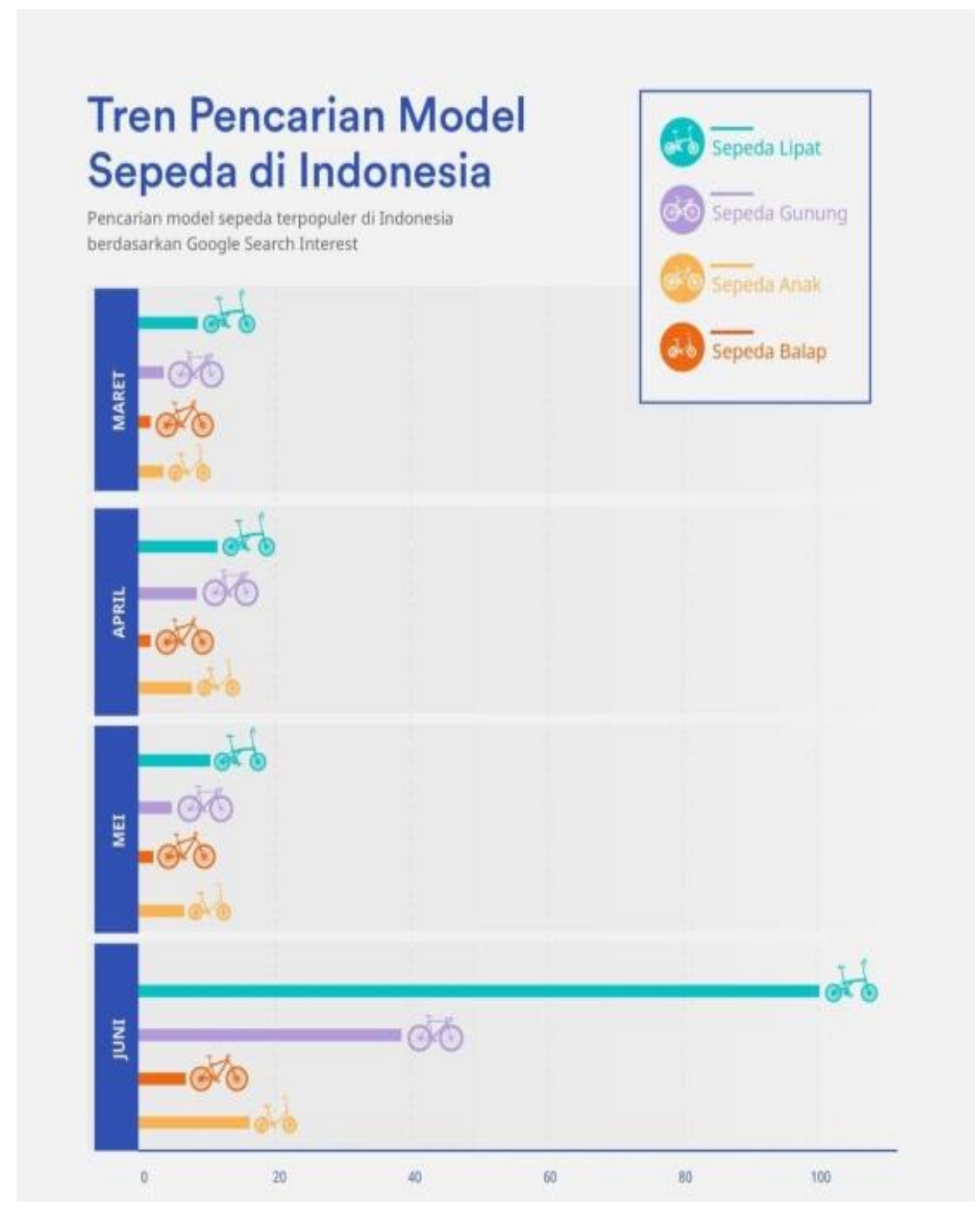

Figure 1. Trends in the Search for Bicycle Models in Indonesia

With the development of technology, the number of internet user is increasing. Most of them comes from the millennials who can never leave their gadgets slipped out of their hands. They have been using it to fulfill their daily needs and using it to do business .(Anugrah, 2020). This can be seen by the trend of online search about the current model of bicycle. Even though the price is fantastic, but the people are having no problem of buying it, not only the bicycle itself but also the spare parts and the accessories.

Riding a bicycle becomes one of the new habits of the society that appears during the pandemic. The researcher throws a survey from September $4^{\text {th }}$ to September $7^{\text {th }} 2020$, involving 1.047 respondents who gave multiple answers, meaning that every respondent might have one or two bicycle at their possession. The bicycle that their own, became an image of themselves. It is also becoming a hobbies for the bicycle owner to look for a community to fulfill their hobbies, then this community make a bond as 
fellow bicycle rider where they get to know each other and form a bicycle club. (Septika et al., 2019)

As the result, mountain bike become the most popular type that were used by most of the bicycle rider in Jakarta by $59 \%$, meanwhile folding bike comes the second place with $32 \%$, $21 \%$ of the society used a city bike, $17 \%$ of them used BMX, $13 \%$ used the road bike, and last but not least, $10 \%$ of them used the fixed gear bike or well known as fixie and touring bike.

Although bicycle riding during the pandemic become the first option as the bored killing activity at home during the pandemic, bicycle riding has also become a new trend among the society. They usually seen in a large group forming a community. Some of the bicycle community admitted that they grew large in number during the pandemic. This community is not only established for the communication but also exchanging or event selling the bicycle, its spare parts and also its accessories, throughout the internal communication group there is a large amount of the transaction involving the small medium enterprises, because sometimes the member of the group is a bicycle rider and a bike shop owner.

The cycling trend not only about the sport but also the "building from scratch" trend. Because of the spare time they had during the semi lock-down and WFH period. The bicycle enthusiast has the tendency to increase the value of their bike by adding several touches so the bicycle looks fancy and also they could resell the bicycle with a higher price, simply the hobby is interesting and profitable. The community comes in various backgrounds and activities, such as sport, games, automotive, computer, entrepreneur, and also bicycle (Prawita et al., 2017).

The enforcement of semi-lockdown and Work from Home has affected the Indonesians interest of online shopping. I price summarize the habit of Indonesians online shopping based on the data impression from google analytics during February and March 2020. Digital Based Marketing used to gain costumers, building preferences, and brand promotion, maintaining costumer, and increase selling that leads to profit (Sari et al., 2020)

Shopping interest on Polygon brand is increased 1036\% since the early March 2020 compared to February. Not only in Indonesia, the trend of buying indoor and outdoor bicycle is also occurred in England, as the BBC reported that there has been a $15 \%$ increase of the bicycle buying.

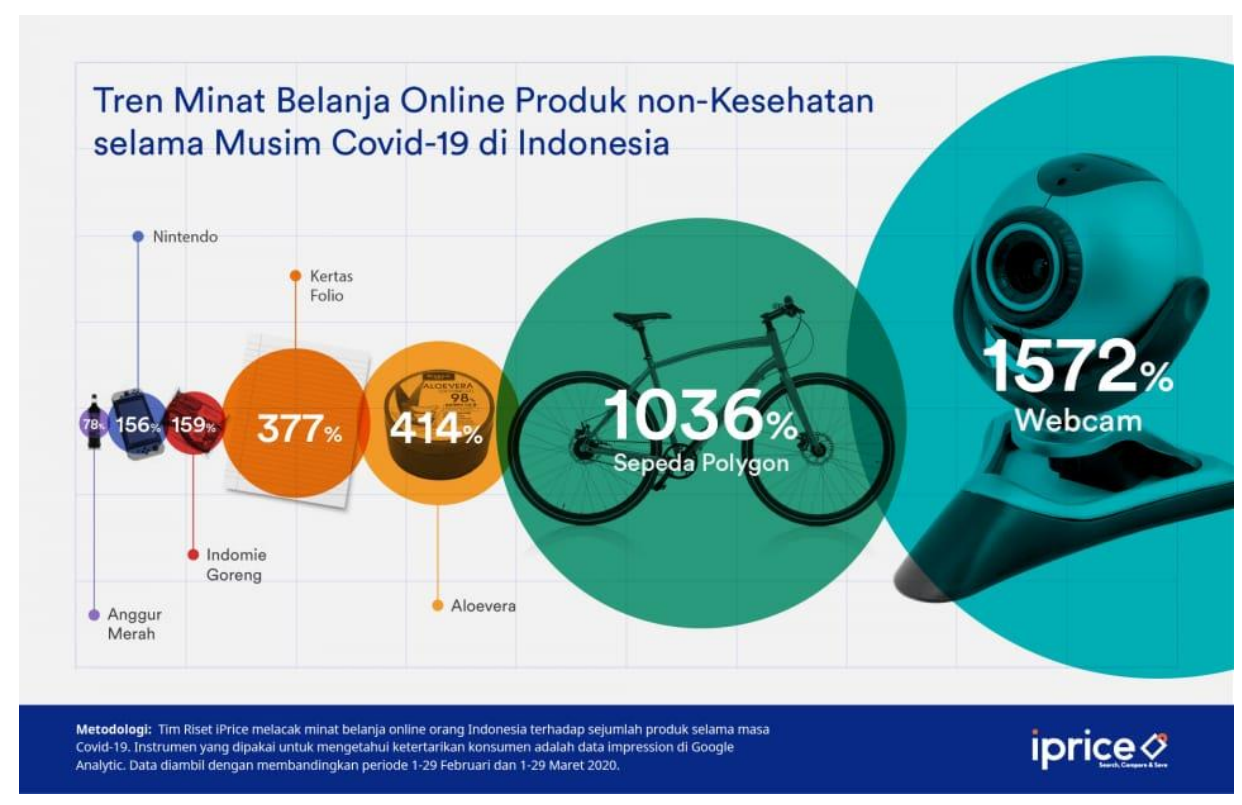

Figure 2. Trends in Online Shopping for Non-Health Products during the Covid 19 Season in Indonesia.

The increase of the cycling trend in Indonesia on the middle of May along with the government plan to loosen the Large Scale of Social Restriction and adapt the new normal. This condition opens the chance of the society to do activity outside since April, $7^{\text {th }} 2020$. With the incredible enthusiast from the society encourage the appearance of seasonal vendor. This phenomenon requires extra precaution to not got tricked by scammer.

The cycling trend brings positive vibes to the domestic small medium enterprise in the domain of bicycle industry, for example PT Insera Sera, the seller of Polygon brand, Sidoarjo East Java based manufacturer experience the increase of $50 \%$ to $200 \%$ of its total demands. Polygon announce that the 
increase was started in the middle of April 2020. Polygon has a major success as their products were sold out in various online shopping platform.

PT Roda Maju Bahagia, a manufacture located in Kendal, Central Java also taste the sweetness of during the pandemics, 150.000 units were sold since January 2020. The bicycle industry was bloom amid the pandemic.

\section{Discussion}

The supporting factor of this trend is, the first one the pandemic has increased the awareness of the society to live a healthy lifestyle, so it can increase the immune to prevent the infection. Daily exercise is a must, even though we were working from home and social distancing so we can be fit and get our immune increased. (Hadi, 2020). In this case, cycling is the best choice because we can be healthy and maintain the health protocol issued by the government to stop the spreading of the Corona virus. The second one is the enthusiast of the society was triggered by the visual content about the cycling exercise shared by athletes or the cycling enthusiast on the social media. The consumption of the information is also increased because people have much time to see it regarding the work from home and social distancing policy.

This trend was supported by the un disturb supply chain of the bicycle, besides the selling activities in the distributor level is still on the go despite the Large-Scale Social Restriction and limited operation. It is also supported with the digital selling done by several store (Kompas: 2020). Many of the small medium enterprise practitioner run their business without any knowledge nor skill about a good business or financial management. Most of them run it by instinct or experience (Fauzi \& Majalengka, 2020). For example, most of the vendor of small and medium enterprise only sell their bicycle, spare parts, or accessories via their WhatsApp status or group.

The government has issued a policy to empower the small medium enterprises in the middle of pandemic situation, there are some scheme applied to protect the small medium enterprises, such as (a) giving monetary aid for the vulnerable small medium enterprise (b) tax incentive for the small medium enterprise (c) credit relaxation and restructure for the small medium enterprise (d) expansion of capital financing aid for the small medium enterprise, and (e) E-learning training. The development of small medium enterprise becoming a strategic sector because of its potential to stimulate the economics activity of the society also as the pedestal of the source of income most of the society to lift up their wellbeing. (Ariani \& Utomo, 2017).

Indonesia were dominated by the existence of small and medium enterprises as the backbone of the national economics of the country was gravely affected, not only from the side of total production but also the commerce value and the number of employee who lost their job due to the pandemic (Alfrian \& Pitaloka, 2020). Beside the shortage of manpower, the enterprise also has to dismissed their employee, in the worst case, the enterprise has to be shut down. In this situation we have to find a business domain that can survive the pandemic.

The key of the national economics restoration is the individual survival and all the business entity. Therefore, the country have to give their best, including giving a stimulation so that the society would not collapse during the critical phase, being productive, and having a proper wage and the business could go on (Hadiwardoyo, 2020). To support the government policies, there are several long terms and short term strategies that have to be considered. The short-term strategies, including the strict health protocol, giving the opportunity and encourage the digital service to support the small medium enterprise activity, socialize the business practitioner, and simplified the administration process, also motivating the change of business strategy. The long-term strategies, regarding the effort of providing road map of the development of the small medium business. Establish the digital technology as a platform in small medium enterprise's business process. The development of small medium enterprise modern business models, and push the collaboration between the government and corporate in the empowerment of small medium enterprise.

There are several recommendations of defensive strategies for the small medium enterprise, so they can survive the situation, such as: (1) doing the online selling via e-commerce because the society has move to the online selling nowadays. (2) utilize the digital marketing to do the promotion to gain more customers. (3) Innovating the product and the service of your business. (4) Doing the customer relationship marketing to earn the trust and loyalty of the costumers. (Hardilawati, 2020).

Several enhancements are needed regarding the value and the attitude of micro business practitioner, mainly about the possibility of sudden change, such as the COVID 19 pandemic situation change. The business practitioner, especially the micro business needs to have a profound knowledge about management of change as their provision to face the fast changing environment (Prianto et al., 2020). This is what the small medium enterprise in the bicycle domain has come through. They doing an online selling which them consider to be more effective, They utilize the Facebook, Instagram, 
community's WhatsApp group, they do not realize that they are indirectly learn the management of change as the answer of the situation. The fast and stable economic growth giving the positive impacts, whether it is directly or indirectly to the wellbeing of the society (Harahap et al., 2020). So, the business practitioner is expected to look for every possible chance under every circumstances to make sure the economics growth is stable

\section{Conclusion}

Based on the research mentioned above, we can vonclude that the cycling trend has the impact of increasing the income of small medium enterprise whether it is online or direct buying, even though the sector of small medium enterprise has been hit hard like in any other countries amid the COVID 19 pandemics, the spirit of stay healthy forced the people to choose exercise as the alternative ways. The most chosen exercise was cycling, because by cycling considered save and still manage to maintain the distance in accordance with health protocol. The cycling trend increase the income of small medium enterprise, where the high-level demands cause the offering price is also increasing. Plus, the hobbies of modifying the bicycle makes the demands of bicycle spare parts is also increasing.

\section{References}

Adityo, I. D. (2017). Peran Komunitas dalam Membangun Kultur Bersepeda (Studi Kasus Pada Komunitas Bike To Work Indonesia di Jakarta). Indonesian Journal of Sociology and Education Policy, 2(2), 5471. https://doi.org/10.21009/ijsep.022.03

Al-Balas, M., Al-Balas, H. I., \& Al-Balas, H. (2020). Surgery during the COVID-19 pandemic: A comprehensive overview and perioperative care. American Journal of Surgery, 219(6), 903-906. https://doi.org/10.1016/j.amjsurg.2020.04.018

Alfrian, G. R., \& Pitaloka, E. (2020). Strategi Usaha Mikro, Kecil, dan Menengah (UMKM) Bertahan Pada Kondisi Pandemik COVID 19 di Indonesia. Sentrinov: Social and Humanities, 6(2), 139-146. https://proceeding.isas.or.id/index.php/sentrinov/article/view/434

Amri, A. (2020). Dampak Covid-19 Terhadap UMKM di Indonesia. BRAND : Jurnal Ilmiah Manajemen Pemasaran, 2(1), 147-153. http://ejournals.umma.ac.id/index.php/brand/article/view/605

Anugrah, R. J. (2020). Efektifitas Penerapan Strategi Online Marketing Oleh UMKM dalam Masa Pembatasan Sosial Berskala Besar (PSBB) Corona Viruses Disease 2019 (Covid-19). Manova (Jurnal Manajemen Dan Inovasi), 3(2), 55-65. https://doi.org/10.15642/manova.v3i2.302

Ardiansyah, T. (2019). Model Financial Dan Teknologi (Fintech) Membantu Permasalahan Modal Wirausaha UMKM Di Indonesia. Majalah Ilmiah Bijak, 16(2), 158-166. https://doi.org/10.31334/bijak.v16i2.518

Ariani, A., \& Utomo, M. N. (2017). Kajian Strategi Pengembangan Usaha Mikro Kecil Dan Menengah (Umkm) Di Kota Tarakan. Jurnal Organisasi Dan Manajemen, 13(2), 99-118. https://doi.org/10.33830/jom.v13i2.55.2017

Fauzi, H., \& Majalengka, U. (2020). Pelatihan Manajemen Keuangan Bagi Pelaku UMKM. BERNAS : Jurnal Pengabdian Kepada Masyarakat, 1(3), 247-255. https://doi.org/10.31949/jb.v1i3.324

Hadi, F. K. (2020). Aktivitas Olahraga Bersepeda Masyarakat Di Kabupaten Malang Pada Masa Pandemi Covid-19. Sport Science and Education Journal, 1(2), 28-36. https://doi.org/10.33365/ssej.v1i2.777

Hadiwardoyo, W. (2020). Kerugian Ekonomi Nasional Akibat Pandemi Covid-19. Baskara Journal of Business and Enterpreneurship, 2(2), 83-92. https://doi.org/10.24853/baskara.2.2.83-92

Handayanto, R. T., \& Herlawati, H. (2020). Efektifitas Pembatasan Sosial Berskala Besar (PSBB) di Kota Bekasi Dalam Mengatasi COVID-19 dengan Model Susceptible-Infected-Recovered (SIR). Jurnal Kajian Ilmiah, 20(2), 119-124. https://doi.org/10.31599/jki.v20i2.119

Hanoatubun, S. (2020). Dampak Covid-19 Terhadap Perekonomian Indonesia. EduPsyCouns: Journal of Education, Psychology, and Counseling, 2(1). https://ummaspul.ejournal.id/Edupsycouns/article/view/423

Harahap, E. F., Luviana, L., \& Huda, N. (2020). Tinjauan Defisit Fiskal, Ekspor, Impor Dan Jumlah Umkm Terhadap Pertumbuhan Ekonomi Indonesia. Jurnal Benefita, 5(2), 151. 
https://doi.org/10.22216/jbe.v5i2.4907

Hardilawati, W. laura. (2020). Strategi Bertahan UMKM di Tengah Pandemi Covid-19. Jurnal Akuntansi Dan Ekonomika, 10(1), 89-98. https://doi.org/10.37859/jae.v10i1.1934

He, F., Deng, Y., \& Li, W. (2020). Coronavirus desease 2019: What we know? Journal of Medical Virology, 92(7). https://doi.org/10.1002/jmv.25766

Nasution, D. A. D., Erlina, E., \& Muda, I. (2020). Dampak Pandemi CoVID-19 terhadap Perekonomian Indonesia. Jurnal Benefita, 5(2), 212. https://doi.org/10.22216/jbe.v5i2.5313

Pakpahan, A. K. (2020). Covid-19 Dan Implikasi Bagi Usaha Mikto, Kecil, Dan Menengah. Jurnal Ilmiah Hubungan Internasional, 1(1), 59-64. https://doi.org/10.26593/jihi.v0i0.3870.59-64

Prawita, R., Swasty, W., \& Aditia, P. (2017). Membangun Identitas Visual Untuk Media Promosi Usaha Mikro Kecil Dan Menengah. Jurnal Sosioteknologi, 16(1), 27-42. https://doi.org/10.5614/sostek.itbj.2017.16.1.3

Prianto, A., Kurniati, I., Wahyudi, M. T., \& Yulistia, E. (2020). Berbagai Faktor Penentu Kesiapan Untuk Berubah Dan Pengaruhnya Terhadap Keberlangsungan Kegiatan UMKM Di Wilayah Terdamak Wabah Covid-19. Capital: Jurnal Ekonomi Dan Manajemen, 4(1), 14. https://doi.org/10.25273/capital.v4i1.7356

Rohmah, S. N., \& Syari, F. (2020). Adakah Peluang Bisnis di Tengah Kelesuan Perekonomian Akibat Pandemi Corona virus Covid-19? ADALAH: Buletin Hukum \& Keadilan, 4(1), 63-74. https://doi.org/10.15408/adalah.v4i1.15448

Sari, D. Y., Darsanto, \& Ismail. (2020). Rancang Bangun Sistem E-Marketing dalam Meningkatkan Pemasaran UMKM (Usaha Mikro, Kecil dan Menengah) di Kabupaten Indramayu. Gema Wiralodra, 11(2), 221-232. https://doi.org/10.31943/gemawiralodra.v11i2.136

Septika, R., Hendarso, Y., \& Soraida, S. (2019). Gaya Hidup Bersepeda pada Komunitas Bike To Work di Kota Palembang. Media Sosiologi: Jurnal Sosiologi Universitas Sriwijaya, 22(1), 31-44. http://jms.fisip.unsri.ac.id/index.php/jms/article/view/31

Sudaryana, Y., Marjohan, M., Nufus, K., Andriani, J., \& Maswarni, M. (2020). Bimbingan Teknis Manajemen Peningkatan Penjualan Melalui E-Commerce Kepada Ikm/Umkm Koperasi Patih Di Kelurahan Cempaka Putih Kecamatan Ciputat Kota Tangerang Selatan Provinsi Banten. Jurnal Pengabdian Dharma Laksana, 3(1), 51. https://doi.org/10.32493/j.pdl.v3i1.6281

Yamali, F. R., \& Putri, R. N. (2020). Dampak Pandemi Covid-19 Terhadap Ekonomi Indonesia. Ekonomis: Journal of Economics, 4(2), 384-388. https://doi.org/10.33087/ekonomis.v4i2.179 